\title{
Serum IgM antibody and influenza A infection
}

\author{
YVONNE I. BUCHNER, R. B. HEATH, J. V. COLlins, AND J. R. PATTISON \\ From the Department of Virology of the Medical Colleges of St. Bartholomew's and The London Hospitals \\ and The Brompton Hospital, London
}

SUMMARY Sucrose density gradient ultracentrifugation followed by haemagglutination inhibition for demonstrating specific influenza $\operatorname{IgM}$ was evaluated as a means of confirming recent infection with influenza A viruses.

Specific IgM antibodies were found in at least one serum obtained from $83 \%$ of patients with proven recent infection with influenza A viruses but in none of the sera from 21 individuals without evidence of infection.

Influenza IgM antibodies persisted for up to 112 days after infection.

The relative merits of detecting specific IgM and complement fixing antibodies for diagnostic purposes are discussed.

It would be very helpful if it proved possible to identify recent infection with influenza viruses by testing a single sample of serum. This applies particularly to patients in hospital when the first serum is generally taken late in the illness and an acute serum for comparison is not available.

It is known that IgM antibodies are present for a transitory period after onset of most viral infections, and their detection is thus indicative of recent infection. The demonstration of specific IgM to influenza viruses would therefore be a useful aid to diagnosis. To this end there have been several studies in which specific $\operatorname{IgM}$ antibodies to influenza $A$ viruses have been identified in the sera of individuals after recent natural infection (Dobrovolskaya, 1971; Daugharty et al., 1972; Brown and O'Leary, 1973; Urquhart, 1974; Buchner et al., 1976). The present study aimed to show the frequency with which sucrose density gradient ultracentrifugation followed by haemagglutination inhibition (HI) could detect specific serum IgM antibodies in patients recently infected with influenza $A$. The results obtained by this technique were compared with the standard complement fixation test.

\section{Material and methods}

VIRUS

The virus used in all haemagglutination-inhibition tests was A/Port Chalmers/1/73 (A/PC/73) which was propagated in fertile hens' eggs.

Received for publication 19 January 1977
SUCROSE DENSITY GRADIENT ULTRACENTRIFUGATION AND HAEMAGGLUTINATION-INHIBITION TESTS

Sera, pre-treated to remove non-specific inhibitors, were fractionated by a modification of the sucrose density gradient method of Desmyter et al. (1971). The serum fractions were tested for $\mathrm{HI}$ activity in microplates. Full details of these methods have been published elsewhere (Buchner et al., 1976). In this study the virus fraction mixtures were incubated either for 60 minutes at room temperature (short incubation) or overnight at $4^{\circ} \mathrm{C}$ (long incubation) before the addition of chick erythrocytes.

COMPLEMENT-FIXATION TESTS

Complement-fixation (CF) tests were carried out in microplates using soluble influenza $\mathbf{A}$ antigen kindly supplied by Dr C. M. P. Bradstreet (Central Public Health Laboratory, Colindale).

\section{SUBJECTS AND SERA}

For the purpose of this study recent infection was regarded as the occurrence of respiratory tract symptoms accompanied by isolation of influenza $\mathbf{A}$ virus and/or a fourfold or greater rise in titres of sequential sera in either CF or HI antibodies.

Sera were obtained from 30 patients with evidence of recent infection with influenza $A$ viruses during the winters of $1973 / 74$ and $1974 / 75$ when $A / P C / 73$ virus was prevalent.

To select a non-infected control group was difficult. Sera were available from 24 individuals in whom it was considered very unlikely that they had recently 
been infected with influenza A viruses. Three of these had taken part in a respiratory viral surveillance study between October 1973 and April 1974, and sera obtained from them had shown unchanging high $\mathrm{HI}$ titres against $\mathrm{A} / \mathrm{PC} / 73$. Two other subjects, members of the laboratory staff, had also shown unchanging high serum $\mathrm{HI}$ titres to influenza A viruses for 18 and 28 months respectively. The remainder (19) of the sera were selected at random from samples submitted to the laboratory for antenatal rubella antibody screening during September 1975 when influenza $A$ was not prevalent. These sera were selected because they had high $(>256)$ HI titres to A/PC/73.

\section{Results}

FREQUENCY WITH WHICH SPECIFIC IgM ANTIBODY COULD BE DETECTED IN PATIENTS WITH PROVEN RECENT INFLUENZA A INFECTION

The standard sucrose density method, in which virus fraction mixtures were incubated for 60 minutes at room temperature, was used in an attempt to detect specific influenza IgM antibodies. Initially, a serum from each of the 30 patients with a confirmed influenza A infection was tested. These 30 sera were obtained between 14 and 60 days after the onset of the illness, and IgM antibody was found in $21(70 \%)$ (Table 1$)$. In no instance was specific IgM antibody detectable in serum from the 24 subjects without evidence of recent infection.

Table 1 Comparison of results obtained by short and long incubation methods of detecting specific IgM antibody against influenza $A$ in sera from subjects with and without evidence of recent infection with influenza

\begin{tabular}{|c|c|c|c|c|}
\hline & \multicolumn{2}{|c|}{ No. of subjects tested } & \multicolumn{2}{|c|}{$\begin{array}{l}\text { No. of sera containing } \\
\text { specific IgM }\end{array}$} \\
\hline & $\begin{array}{l}\text { Short * } \\
\text { incubation }\end{array}$ & $\begin{array}{l}\text { Long } \dagger \\
\text { incubation }\end{array}$ & $\begin{array}{l}\text { Short } \\
\text { incubation }\end{array}$ & $\begin{array}{l}\text { Long } \\
\text { incubation }\end{array}$ \\
\hline Recent infection $\ddagger$ & 30 & 29 & $21(70.0 \%)$ & $24(82.8 \%)$ \\
\hline No recent infection & 24 & 19 & $0(0 \%)$ & $0(0 \%)$ \\
\hline
\end{tabular}

*Virus/fraction mixtures incubated for one hour at room temperature. + Virus/fraction mixtures incubated overnight at $4^{\circ} \mathrm{C}$.

†Samples from infected individuals were taken from 14 to 60 days after onset of symptoms.

In an attempt to increase the sensitivity of the method for detecting specific IgM, the incubation of virus-fraction mixtures was extended from one hour at room temperature to 18 hours at $4^{\circ} \mathrm{C}$. This modification resulted in the detection of specific IgM antibodies in a further three subjects with confirmed influenza, so that specific macroglobulins were detected in $83 \%$ of the sera from this group. This more sensitive test did not detect specific IgM antibody in sera from any subject without recent infection.

Because of its increased sensitivity the long incubation method was used for all subsequent assays.

Figure 1 shows the distributions of the levels of $\mathrm{HI}$ activity in the sera of patients with evidence of recent infection (IgM positive) and in the sera of the controls (IgM negative). It can be seen that, although there was a slight tendency for the IgM positive sera to have higher HI titres, the two distributions were remarkably similar. This clearly shows that with high titred sera from individuals without evidence of recent infection the leading edge of the IgG peak does not extend into the IgM-containing fraction and thus give false positive results.

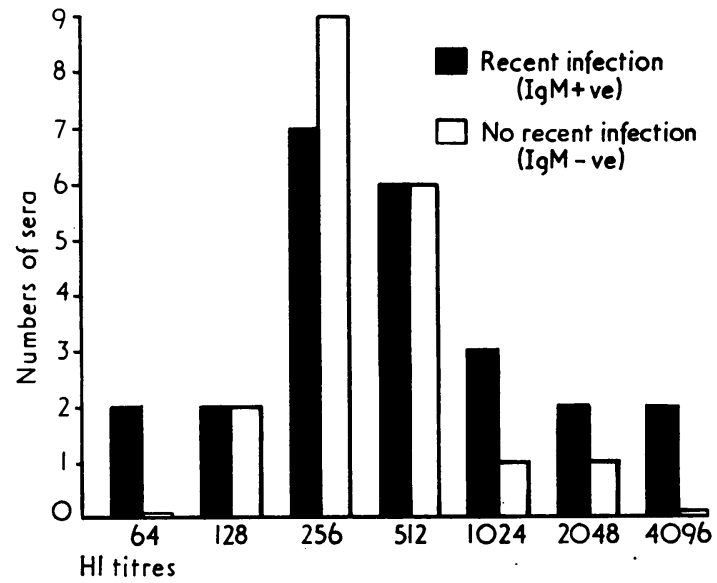

Fig. 1 Serum HI titres against A/PC/73 in (a) 24 sera from patients with evidence of recent infection with influenza A virus (IgM positive), and (b) 19 selected individuals with no evidence of recent infection (IgM negative).

DURATION OF ANTIBODIES OF THE IgM CLASS IN PATIENTS RECENTLY INFECTED WITH INFLUENZA A VIRUS

A total of 93 sera were available from patients with $\mathcal{O}$ confirmed recent influenza A. Table 2 shows the relationship between the occurrence of specific IgM antibodies in these sera and the time since the onset $\omega$ of symptoms.

Only two of the 20 sera $(10 \%)$ taken within seven 6 days of the onset of symptoms had detectable IgM antibody. These sera were taken on the fifth and sixth days of the illness. The remaining 18 sera had influenza A HI titres ranging from 8 to 512, and all the HI antibody detectable after fractionation was in the IgG-containing fractions. Eight of these sera had titres of 32 or less, and it is possible that the 
Table 2 Results of testing sera from patients with proven recent infection with influenza $A$ virus, showing relationship between time since onset of symptoms and presence of specific IgM antibodies in serum

\begin{tabular}{cllc}
\hline $\begin{array}{l}\text { Days after } \\
\text { onset }\end{array}$ & $\begin{array}{l}\text { No.patients } \\
\text { tested }\end{array}$ & $\begin{array}{l}\text { No. sera } \\
\text { tested }\end{array}$ & $\begin{array}{l}\text { No. of sera containing } \\
\text { specific IgM }\end{array}$ \\
\hline $0-7$ & 19 & 20 & $2(10 \%)$ \\
$8-14$ & 19 & 19 & $12(63 \%)$ \\
$15-28$ & 15 & 18 & $14(78 \%)$ \\
$29-60$ & 16 & 18 & $16(89 \%)$ \\
$61-112$ & 5 & 7 & $5(71 \%)$ \\
$113-346$ & 5 & 11 & $0(0 \%)$ \\
\hline
\end{tabular}

fractionation procedure would dilute any specific IgM present below the level of detection. With the remaining 10 sera it must be presumed that they contained previously acquired influenza $A$ antibody which cross-reacted with the A/PC/73 antigen used in this study.

The frequency with which specific IgM antibody was detected increased with sera taken after the first week of the illness. Twelve of the 19 sera (63\%) taken during the second week after onset contained specific IgM.

Of the sera obtained between the 15th and 112th days after onset, 35 out of $43(81 \%)$ were found to contain specific IgM. There was no obvious difference in the frequency with which specific macroglobulins were detected during this period apart from a possible decline between the 61st and 112 th days after onset.

None of the 11 sera obtained from patients 113 days or more after the onset of their illness contained specific IgM antibodies.

The rate of decline of influenza IgM antibodies was studied in five patients from whom sequential blood specimens were obtained. The results are shown in Figure 2. The duration of this class of specific antibody varied widely. Specific IgM had disappeared from the serum of one individual by the 42nd day after the onset of symptoms. At the other extreme, specific IgM was still detected in the serum of another patient 112 days after onset but had disappeared by the 133rd day.

COMPARISON BETWEEN SPECIFIC IGM AND CF METHODS OF DETECTING RECENT INFECTION WITH INFLUENZA A

It is usual laboratory practice to report that high serum CF antibody titres ( $>256$ ) against influenza soluble antigens are strongly suggestive of recent infection and that intermediate titres (128-256) indicate possible recent infection. The relative merits of the CF and specific IgM procedures for detecting recent infection were assessed by testing sera by both methods.

In general, there was reasonable agreement between the two methods (Table 3). It can be seen that 19 out of the 27 IgM positive sera had CF titres which suggested recent infection. However, the remaining 8 of these 27 sera would have been reported negative if only complement fixation had been used.

Six out of the seven IgM negative sera, obtained from recently infected patients, gave CF results which suggested recent infection, three having titres of $>256$ and three titres of 128 and 256. The remaining IgM negative serum from this group would have been missed by both techniques if only a single serum sample had been examined. This patient had shown fourfold rises in both HI (64/512) and CF (8/64) antibodies after an influenza-like illness.

In the group with no evidence of recent infection with influenza A, and no detectable specific IgM, 21 out of 26 sera $(80.8 \%)$ had low-titre $(<128) \mathrm{CF}$ antibody. Five of these 26 cases $(19 \cdot 2 \%)$, however, had moderately high CF antibody titres (128-256) which may possibly have been regarded as indicative of recent infection. This interpretation would certainly have been erroneous in one patient since the sera from this individual had shown persisting

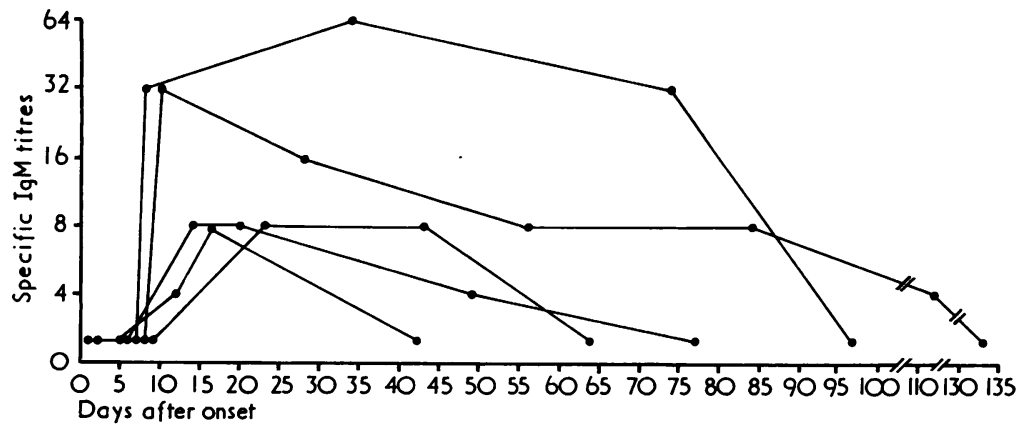

Fig. 2 Levels of influenza IgM antibodies (anti-A/PC/73 HI titres of fraction 2) in the sera of five patients at various intervals after onset of symptoms. 
Table 3 Relationship between CF titres and presence of specific influenza A IgM in 60 sera from subjects with and without evidence of recent infection with influenza $A$ virus

\begin{tabular}{|c|c|c|c|c|c|c|}
\hline \multirow[t]{2}{*}{ Category } & \multirow{2}{*}{$\begin{array}{l}\text { Specific IgM } \\
\text { present }\end{array}$} & \multicolumn{3}{|c|}{ Influenza $A$ CF titre } & \multirow[t]{2}{*}{ Total tested } & \multirow{2}{*}{$\begin{array}{l}\text { GMT of influenza } \\
A C F \text { titres }\end{array}$} \\
\hline & & $<128$ & $128-256$ & $>256$ & & \\
\hline Recent infection & + & 8 & 10 & 9 & 27 & $122 \cdot 34$ \\
\hline Recent infection & - & 1 & 3 & 3 & 7 & $33 \cdot 29$ \\
\hline No recent infection & - & 21 & 5 & 0 & 26 & \\
\hline
\end{tabular}

levels of CF antibody at a titre of 256 for 28 months after infection with $\mathrm{A} /$ England/42/72.

\section{Discussion}

The demonstration of rising titres of antibody in paired sera, by either CF or $\mathrm{HI}$, is a well proven method for diagnosing recent infection with influenza. A difficulty, however, is experienced in hospital practice when attempts are made to demonstrate that influenza has been an initiating factor in more serious chest disease such as pneumonia, exacerbations of chronic bronchitis, and asthma because sera from the early viral stages of these illnesses are rarely available. Complement fixation tests can be used on these occasions since the first available sera from such cases usually contain high levels of antibody against a soluble influenza antigen and this antibody is often transitory. However, the unreliability of complement fixation when carried out on single sera, obtained in the convalescent period, is well known. There are two reasons for this, both of which were revealed in this study. First, not all individuals develop sufficiently high levels of antibody to suggest recent infection. In the present series, only 25 of the 34 sera tested had CF antibody titres of 128 or greater. Secondly, there are others who retain high levels of this kind of antibody for long periods, titres of 128 or greater being found in five of the 26 control patients with no evidence of recent infection.

Detection of specific influenza IgM appears to be a more satisfactory test. This class of antibody was not detectable in any of the sera from the control patients. However, IgM was detected in at least one serum from 26 of the 30 patients with confirmed influenza. Although this is encouraging, it is apparent that the sucrose density method of detecting specific influenza IgM is less satisfactory than the corresponding procedure used for rubella. With the latter, specific IgM can be detected in virtually every serum with an HI antibody titre of 32 or greater collected within four weeks of the onset of the rash (Pattison and Mace, 1975). The comparative insensitivity of the influenza IgM test is possibly due to a relative insensitivity of the influenza $\mathrm{HI}$ test as an indicator of the presence of specific IgM antibody. In the present series some improvement in the frequency of detection of specific IgM could be achieved by using a more sensitive HI test incorporating overnight incubation of virus and antibody. Furthermore, any relative insensitivity of the influenza $\mathrm{HI}$ test may be aggravated by the procedures for the removal of non-specific inhibitors. We have previously shown that receptor destroying enzyme treatment regularly leads to some diminution in specific influenza $\mathrm{HI}$ titre (Buchner et al., 1976).

It is also possible that individuals produce less IgM class antibody after infection with influenza than they do after rubella. This may be due to the fact that much influenza infection takes place against a background of cross-reacting antibody produced by previous infections. Increasing the sensitivity of the antibody detecting system would improve the efficiency of the specific influenza IgM test.

Overall in the present series, specific IgM antibody was detected in at least one serum from 24 of the 30 confirmed cases of recent influenza. Thus, although the detection of specific influenza IgM is too elaborate for routine use, it should prove useful in special investigations in which only single convalescent sera are available.

\section{References}

Brown, G. C. and O'Leary, T. P. (1973). Fluorescent antibodies to influenza virus in various immunoglobulin fractions of serum after natural infection or vaccination. Journal of Immunology, 110, 889-896.

Buchner, Y. I., Heath, R. B., Collins, J. V., and Pattison, J. R. (1976). Detection of antibodies of the IgM class in sera of patients recently infected with influenza viruses. Journal of Clinical Pathology, 29, 423-427.

Daugharty, H., Davis, M. L., and Kaye, H. S. (1972). Immunoglobulin class of influenza antibodies investigated by radioimmunoassay (RIA). Journal of Immunology, 109, 849-856.

Desmyter, J., South, M. A., and Rawls, W. E. (1971). The IgM antibody response in rubella during pregnancy. Journal of Medical Microbiology, 4, 107-114.

Dobrovolskaya, N. G. (1971). Formation of antibodies of different classes in influenzae infections. Journal of Hygiene, Epidemiology, Microbiology and Immunology, 15, 148-155. 
Pattison, J. R. and Mace, J. E. (1975). The detection of specific IgM antibodies following infection with rubella virus. Journal of Clinical Pathology, 28, 377-382.
Urquhart, G. E. D. (1974). Serum IgM and IgA responses in influenza A infections. Journal of Clinical Pathology, 27, 198-201.

\section{Reports and Bulletins prepared by the Association of Clinical Biochemists}

The following reports and bulletins are published by the Association of Clinical Biochemists. They may be obtained from The Publishing Department, British Medical Journal (ACB Technical Bulletins), B.M.A. House, Tavistock Square, London WC1H 9JR. Overseas readers should remit by British Postal or Money Order.

SCIENTIFIC REPORTS (price $£ 1.00 / \$ 2.00$ each)

3 Automatic dispensing pipettes: an assessment of 35 commercial instruments September 1967 P. M. G. BROUGHTON, A. H. GOWENLOCK, G. M. WIDDOWSON, and K. A. AHLQUIST

4 An evaluation of five commercial flame photometers suitable for the simultaneous determination of sodium and potassium March 1970 P. M. G. BROUGHTON and J. B. DAWSON

SCIENTIFIC REVIEWS (price $£ 1 \cdot 00 / \$ 2.00$ each)

1 The assessment of thyroid function March 1971 F. V. FLYNN and J. R. HOBBS

2 Renal function tests suitable for clinical practice January 1972 F. L. MITCHELL, N. VEALL, and R. W. E. WATTS

3 Biochemical tests for the assessment of fetoplacental function May 1975 C. E. WILDE and R. E. OAKEY

4 Test of exocrine pancreatic function March 1977 A. H. GOWENLOCK

TECHNICAL BULLETINS (price $£ 1.00 / \$ 2.00$ each)

9 Determination of urea by AutoAnalyzer November 1966 RUTH M. HASLAM

11 Determination of serum albumin by AutoAnalyzer using bromocresol green October 1967 B. E. NORTHAM and G. M. WIDDOWSON

13 An assessment of the Technicon Type II Sampler Unit March 1968 B. C. GRAY and G. K. MCGOWAN

14 Atomic absorption spectroscopy: an outline of its principles and a guide to the selection of instruments May 1968 J. B. DAWSON and P. M. G. BROUGHTON

15 A guide to automatic pipettes (2nd edition) June 1968 P. M. G. BROUGHTON

16 A guide to automation in clinical chemistry May 1969 P. M. G. BROUGHTON

17 Flame photometers: a comparative list of 17 instruments readily available in Britain August 1969 P. WILDING

19 Spectrophotometers: a comparative list of low-priced instruments readily available in Britain May 1970 C. E. WILDE and P. SEWELL
20 Quantities and units in clinical biochemistry June 1970 P. M. G. BROUGHTON

21 Filter fluorimeters: A comparative list of 18 instruments September 1970 H. BRAUNSBERG and S. S. BROWN

22 Bilirubin standards and the determination of bilirubin by manual and technicon AutoAnalyzer methods January 1971 BARBARA BILLING, RUTH HASLAM, and N. WALD

23 Interchangeable cells for spectrophotometers and fluorimeters September 1971 S. S. BROWN and A. H. GOWENLOCK

24 Simple tests to detect poisons March 1972 B. w. MEADE et al.

\section{Blood gas analysers May 1972 K. DIXoN}

26 Kits for enzyme activity determination September 1972 S. B. ROSALKI and D. TARLOW

27 Assessment of pumps suitable for incorporation into existing continuous flow analytical systems November 1972 A. FLECK et al.

28 Routine clinical measurements of transferrin in human serum September 1973 K. DIXON

29 Control materials for clinical biochemistry (5th edition) September 1973 J. F. STEVENS

30 Notes on the quality of performance of serum cholesterol assays September 1973 s. S. BROWN

31 Determination of uric acid in blood and in urine July 1974 R. W. E. WATTS

32 A survey of amino acid analysers readily available in the United Kingdom September 1974 J. E. CARLYLE and P. PURKISS

33 Definitions of some words and terms used in automated analysis November 1974 A. FLECK, R. ROBINSON, S. S. BROWN, and J. R. HOBBS

34 Measurement of albumin in the sera of patients January 1975 LINDA SLATER, P. M. CARTER, and J. R. HOBBS

35 Investigation of the validity of temperature correction factors for serum aspartate and alanine transaminases March 1975 s. B. ROSALKI et al.

36 Factors influencing the assay of creatinine November 1975 J. G. H. COOK 